\title{
Planularia kintradwellensis sp. nov. (Foraminifera), a distinctive biostratigraphical marker species for the Lower Kimmeridgian of the U.K.
}

\author{
FRANCIS JOHN GREGORY \\ Paleo Services, \\ Unit 15, \\ Paramount Industrial Estate, \\ Sandown Road, \\ Watford, WD2 4XA
}

\begin{abstract}
A foraminiferal species, Planularia kintradwellensis sp. nov., previously left in open nomenclature, is shown to have a useful short stratigraphical range. It has been recovered from several onshore sites within the UK and only from the Lower Kimmeridgian. J. Micropalaeontol., 11 (2), 135-140, December 1992.
\end{abstract}

\section{INTRODUCTION}

After examination of several unpublished sources in conjunction with the author's research on foraminifera from Jurassic onshore outcrops of Scotland it has become apparent that a foraminiferid taxon previously left in open nomenclature as Planularia sp. A (Gregory 1986, 1989) has a useful and short stratigraphical range. Planularia kintradwellensis first appears and is restricted to the baylei -mutabilis Zones of the Lower Kimmeridgian. So far this particular taxon has been positively identified from several onshore Upper Jurassic UK sites (Fig. 1) and recovery within this area is quite extensive ranging from separate basins of the North Sea and Hebrides in North East and North West Scotland respectively. Interestingly, this form was also recovered from the Dorset area (Lloyd, 1958), representing the Wessex Basin of Southern England.

One reason for publishing is to elicit further occurrences from other offshore Jurassic deposits of the North Sea, Hebridean and Irish Sea Basins. From the limited amount of data released from oil company offshore wells it is apparent that these deeper water deposits are dominated by agglutinated faunas (e.g. Nagy 1985a, b; Lofaldi et al. 1983; Morris 1989; Morris \& Dyer 1990 and P.Copestake, pers.comm. 1986, 1989). However, calcareous forms do occur in these deeper water facies, but they are not as evident as in the shallower water deposits, represented by the onshore sections (Fig. 1). This transition from calcareous dominated to agglutinated dominated microfaunas is also apparent when examining the onshore Inner Moray Firth Basin sequences from Helmsdale to Eathie Haven in NE Scotland. Facies type indicates that these deposits represent at the former a shallow water, near shore shelf that was a fairly well oxygenated environment dominated by calcareous foraminifera (Gregory, 1986, 1989) grading to the latter which represents deeper water, occasionally anoxic, hemipelagic shale basinal deposits dominated by agglutinated foraminifera.

This trend is also corroborated by an increase in the radiolaria (planktonic): foraminifera (benthonic) ratio basinwards. This simple quantitative method is used here in lieu of the usual water depth/distance from palaeo-shore

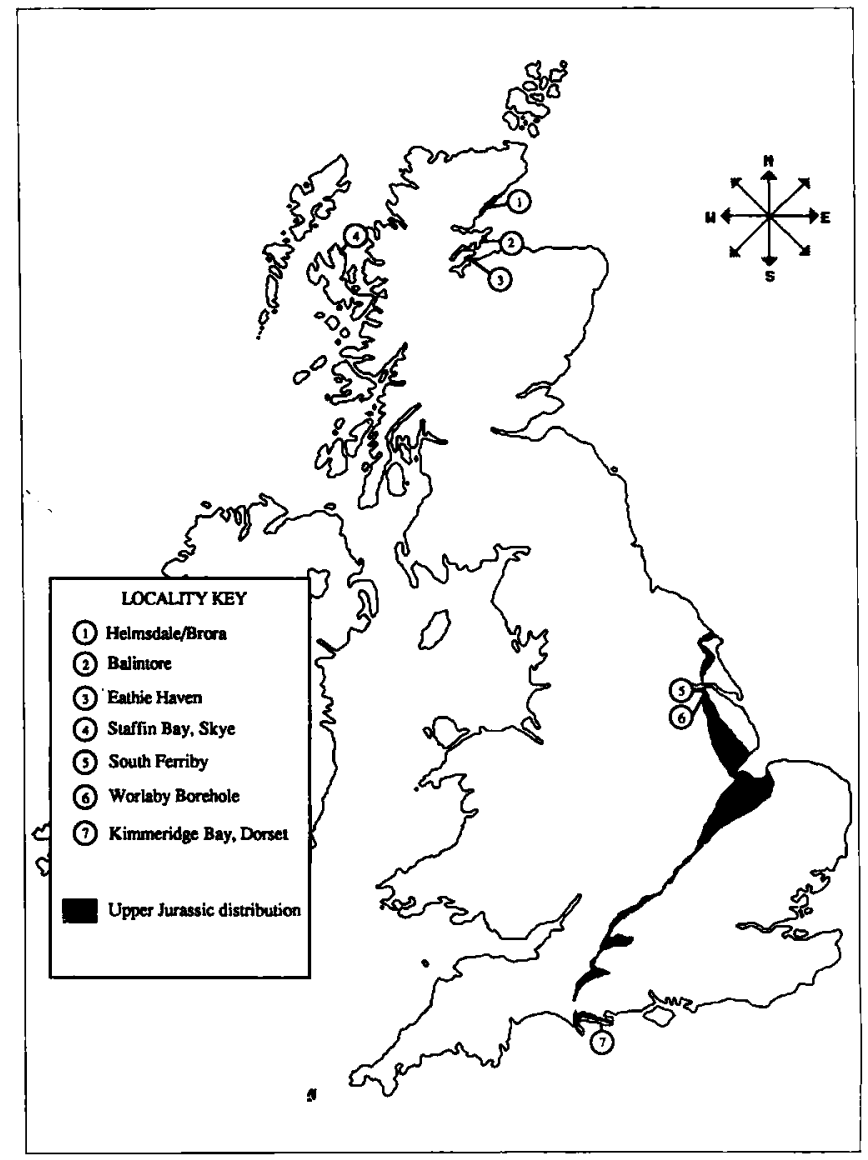

Fig. 1. Upper Jurassic outcrop in the United Kingdom with an indication of sites mentioned in the text including localities where Planularia kintradwellensis occurs.

indicator of the planktonic foraminifera to benthonic foraminifera ratio more usually used in Cretaceous and Recent sequences. 


\section{SYSTEMATIC DESCRIPTION}

The monumental suprageneric classification of foraminiferids by Loeblich \& Tappan (1988) is utilised here, which in turn is based on earlier exploratory works (Loeblich \& Tappan, 1964, $1974,1984)$. The number of suprageneric groups have more than doubled in the period 1964-1988, with an increase from five to twelve suborders, including the elevation of Lagenina.

Loeblich \& Tappan (1988) continue to group all the foraminifera within one order following the recommendations of the protozoan classification committee of Levine et al. (1980). However, various authors advocate the elevation of foraminifera to class or subclass (e.g. Haynes, 1989), or even to phylum level (Margulis, 1974). In the absence of a consensus of opinion on this issue, the higher classificatory system of Levine et al. (1980) is accepted here.

The classification of Loeblich \& Tappan is the mostcomplete and up to date scheme available and is used here, but with some reservations. The authors tend to be somewhat overzealous in the taxonomic splitting of genera using surface ornamentation. For example the genus Dentalina is now reserved for only longitudinally costate forms. Smooth or discontinously costate forms are now collected within Prodentalina, Paradentalina, Mesodentalina or Laevidentalina. Their stated purpose in following this practice is to allow evolutionary sequences to be more naturally defined; but, as environment is also observed to control the development of these features, such splitting must be viewed with caution. Also, splitting of genera tends to be somewhat cumbersome and confusing to non-specialists.

Order Foraminiferida Eichwald, 1830

Suborder Lagenina Delage \& Hérouard, 1896

Superfamily Nodosariacea Ehrenberg, 1838

Family Vaginulinidae Reuss, 1860

Subfamily Vaginulininae Reuss, 1860

Genus Planularia DeFrance, 1826

Diagnosis. Planularia is characterised by its loose, flat uniserial coil. Initial 3-6 chambers in a fairly tight coil succeeded by an uncoiled uniserial section.

Remarks. This genus was recently involved in a proposed conservation to the Bulletin of Zoological Nomenclature by Hansen \& Rögl (1986) who suggested suppression of its unused senior subjective synonym Linthuris de Montfort 1808. Planularia appears to have been vindicated as the correct name (Hansen pers. comm., 1991 and Opinion 1571, 1990).

\section{Planularia kintradwellensis}

(Fig. 2, A-D)

1958 Planularia curticostata Lloyd: p. 128, pl. 15, fig. 2a-b. 1986 Planularia sp. A. Gregory: p.126, pl. 4, figs. 1-4. 1987 Saracenaria sp. 2 Young: p. 217, pl. 17, fig. 6. 1989 Planularia sp. A Gregory: Gregory,p. 184, pl. 2.2.1, fig. 1.

Derivation of name. After Kintradwell Farm, (Grid Reference 0730 9330) North Sutherlandshire, NE Scotland, which also gives its name to the type formation, the Kintradwell Boulder Beds.
Material.HELMSDALE(type locality): 109 specimens cymodoce -mutabilis Zones (Gregory 1986, 1989).

EATHIE HAVEN:12specimens baylei-cymodoce Zones(present work).

FLODIGARRY: 6 specimens baylei Zone (Young, 1987 and present work).

BLACKHEAD, Dorset: several specimens from the base of the mutabilis Zone (Young, 1987 and Lloyd, 1958).

Description. Test free, medium to large with a compressed, loose planispiral coil; rounded proximal periphery, distal periphery usually keeled; 6-12 rounded chambers, greater in width than height, gradually increasing in size as added, final chamber inflated and almost always partially envelops the proloculus; proloculus small, oval, unornamented; sutures distinct, deeply depressed, arcuate; test wall calcareous, ornament distinct, forming short, coarse irregular ribbing on the base of the chambers, which does not cross sutures; final chamber marked by a series of coarse, cord like ribs: 2 peripheral, 1 distal rib/keel and 2 ribs occurring centrally, these 5 ribs/keels converge on the apertural neck; aperture distinct, peripheral, raised on a short neck, thick notched collar with the ribs converging to form thick apertural bars. Microspheric and megalospheric generations can be identified, the latter possess a more rounded proximal region, whilst the former tend to be more pointed.

Dimensions. Holotype; Maximum length $313 \mu \mathrm{m}$, maximum width $175 \mu \mathrm{m}$. (Megalospheric).

Paratype; Maximum length $271 \mu \mathrm{m}$, maximum width $182 \mu \mathrm{m}$. (Megalospheric).

Remarks. This form resembles Planularia beierana (Gümbel) 1862 and Planularia eugenii (Terquem) 1864. It differs from the former in having ornamentation and from the latter by its more irregular, but distinct ribbing. This species was previously recorded as Planularia curticostata by Lloyd (1958) in an unpublished Ph.D. thesis. Lloyd (1959, 1962) published accounts on the distribution of agglutinated, miliolid, and polymorphinid foraminifera from the type Kimmeridgian in Dorset but did not include the diverse nodosariid faunas he had recovered. Under Rule 8a of the International Code of Zoological Nomenclature (Ride, 1985), a species name is invalid if it is nominated in a publication that is not widely disseminated or in a readily available format.

Young (1987, unpublished Ph.D. thesis) recorded a few forms that were assigned to Saracenaria sp. 2 from selected sites in the British Isles. Examination of his material indicates that this form is synonymous with Planularia kintradwellensis and represents forms that have a looser coiling mode. It is hypothesized here that coiling mode is perhaps an environmentally controlled feature and the triangular section, normally a saracenarid feature is also enhanced by the presence of the rather coarse keel.

\section{STRATIGRAPHICAL OCCURRENCE}

Planularia kintradwellensis has been recovered from several sequences of the Upper Jurassic in the United Kingdom (Figs $1 \& 2$ ). These sections are dealt with below, commencing with the type section of the Kintradwell Boulder Beds at Helmsdale, NE Sutherlandshire. Apparently a form 


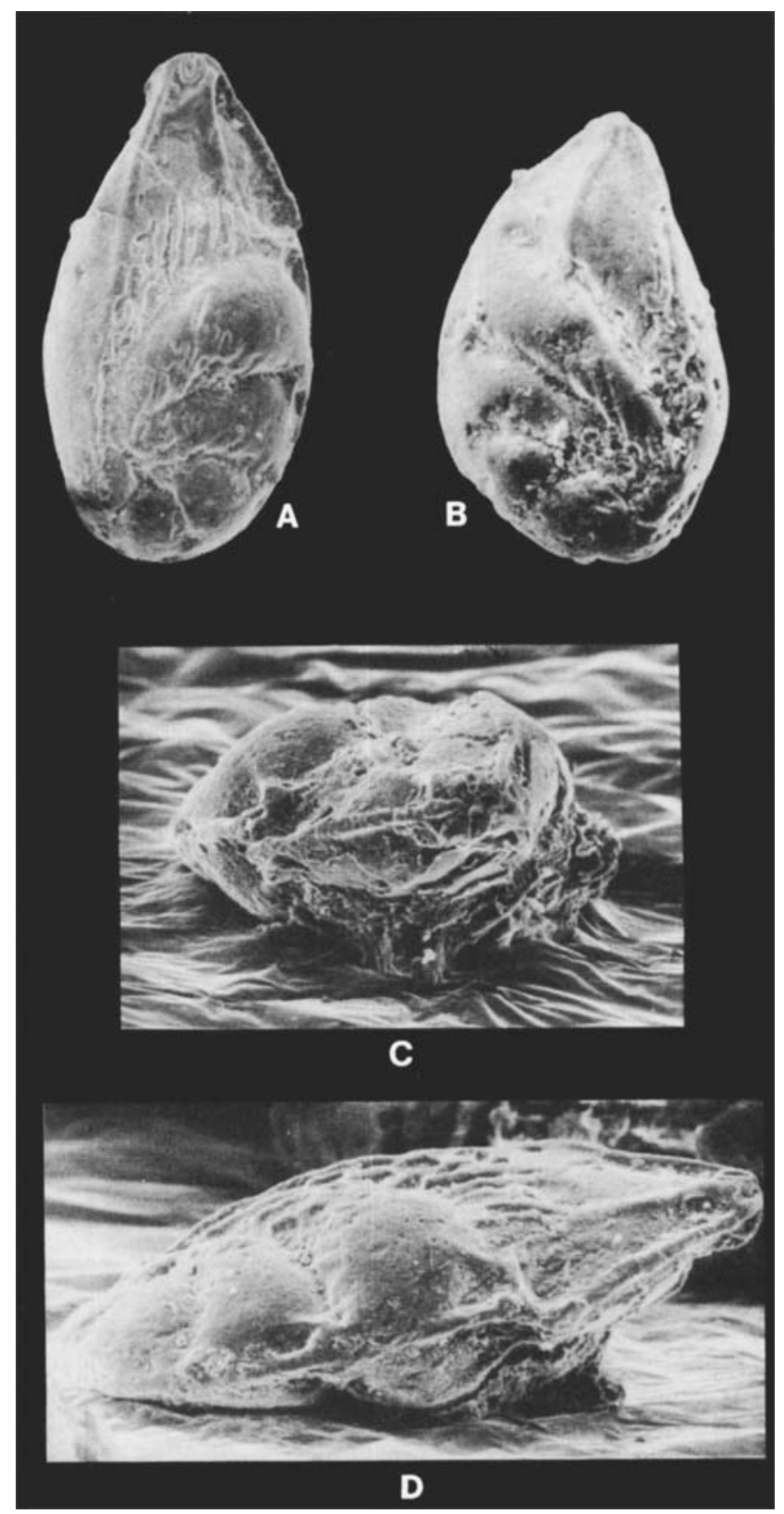

Fig. 2. Fig. A. Holotype, to be deposited in the Natural History Museum, London; length: $313 \mu \mathrm{m}$; locality: Kintradwell Boulder Beds, Helmsdale; Fig. B. Paratype, to be deposited in the Natural History Museum, London; length: $270 \mu \mathrm{m}$; locality: Kintradwell Boulder Beds, Helmsdale; Fig. C. Apertural view of the Holotype; Fig. D. Peripheral view of the Holotype.

similar to $P$. kintradwellensis has also been recovered from the Inner Moray Firth offshore deposits, but no published material is available (P.Copestake, pers. comm. 1990).

1) Helmsdale/Brora, Sutherland, NE Scotland (Grid Ref. NC92550713, Fig. 1 Point 1).

Foraminifera from the Kintradwell 'Boulder Beds' of the Helmsdale Brora Outlier have already been described by
Gregory $(1986,1989)$ for the Lower Kimmeridgian (cymodocemutabilis Zones). Further work on the entire sequence spaning the upper series of the Helmsdale Boulder Beds from the autissiodorensis to albani Zones has failed to recover any further specimens of Planularia kintradwellensis. The facies represent shallow water deposits and clasts forming the boulder beds transported during syn-depositionary development of the Helmsdale Fault into contemporaneous, deeper water shales and fine grained calcareous sandstones.

This section has provided the largest number of specimens for study and is nominated as the type section. The ammonite biostratigraphy has been defined by Buckman (1932) and Linsley (1972), with the upper part of the Boulder Bed sequence more reliably dated by palynological studies of Riley (1980) and Barron (1989). Planularia kintradwellensis has its first appearance and acme in the cymodoce Zone and final appearance in the mutabilis Zone.

\section{2) Eathie Haven, Cromarty and Ross (Grid Ref. NH77796325,} Fig. 1 Point 3).

This diminutive Lower Kimmeridgian exposure on the Black Isle, Cromarty is limited by erosion between the top of the baylei Zone to the lower part of the mutabilis Zone. Ammonite biostratigraphy used as the template follows the work of Waterston (1950,1951), Lee (1925), Lee \& Pringle (1932) and Zeigler (1962a, 1962b).Waterston (1951) also studied the foraminifera, but only published a list of forms retrieved. The present study concentrated 45 samples across this sequence. As a facies it is equivalent in age to the deposits of the Helmsdale/Brora Outlier and represents somewhat deeper water deposition, related to further depositional distance from shore. This is reflected in the predominance of radiolaria and agglutinated foraminifera. Calcareous forms are subordinate, but Planularia kintradwellensis occurs amongst them and is limited to the topmost part of the baylei Zone and the cymodoce Zone.

\section{3) Flodigarry, Staffin Bay, NE Skye (Grid Ref. NG46867149,} Fig. 1 Point 4).

The ammonite biostratigraphically is well established following Sykes (1975) and Sykes \& Callomon (1979) for the Callovian to Oxfordian and Wright $(1973,1990)$ and Turner $(1966,1970)$ for the Kimmeridgian. The sections at Flodigarry are tectonically disturbed, but it is still possible by careful correlation of the limestone marker beds to match up sections. The Callovian to the Lower Kimmeridgian is part of the author's research on the foraminiferal and radiolarian distribution in Scotland (Fig. 1, points 1-4) and there is some overlap with the previous work of Young (1987) who studied the Lower Kimmeridgian at Staffin Bay. The author's sections were arranged to test the first appearance of the typical Kimmeridgian microfaunas. Planularia kintradwellensis was recovered from the baylei and lower most cymodoce Zones, with no occurrences in the Oxfordian or Callovian sequences (Gregory in prep.).

4) Blackhead, Dorset (Grid Ref. Fig. 1 Point 7).

This section has been nominated elsewhere as the type subBoreal Lower Kimmeridgian (see Ziegler 1962b). Ammonite 


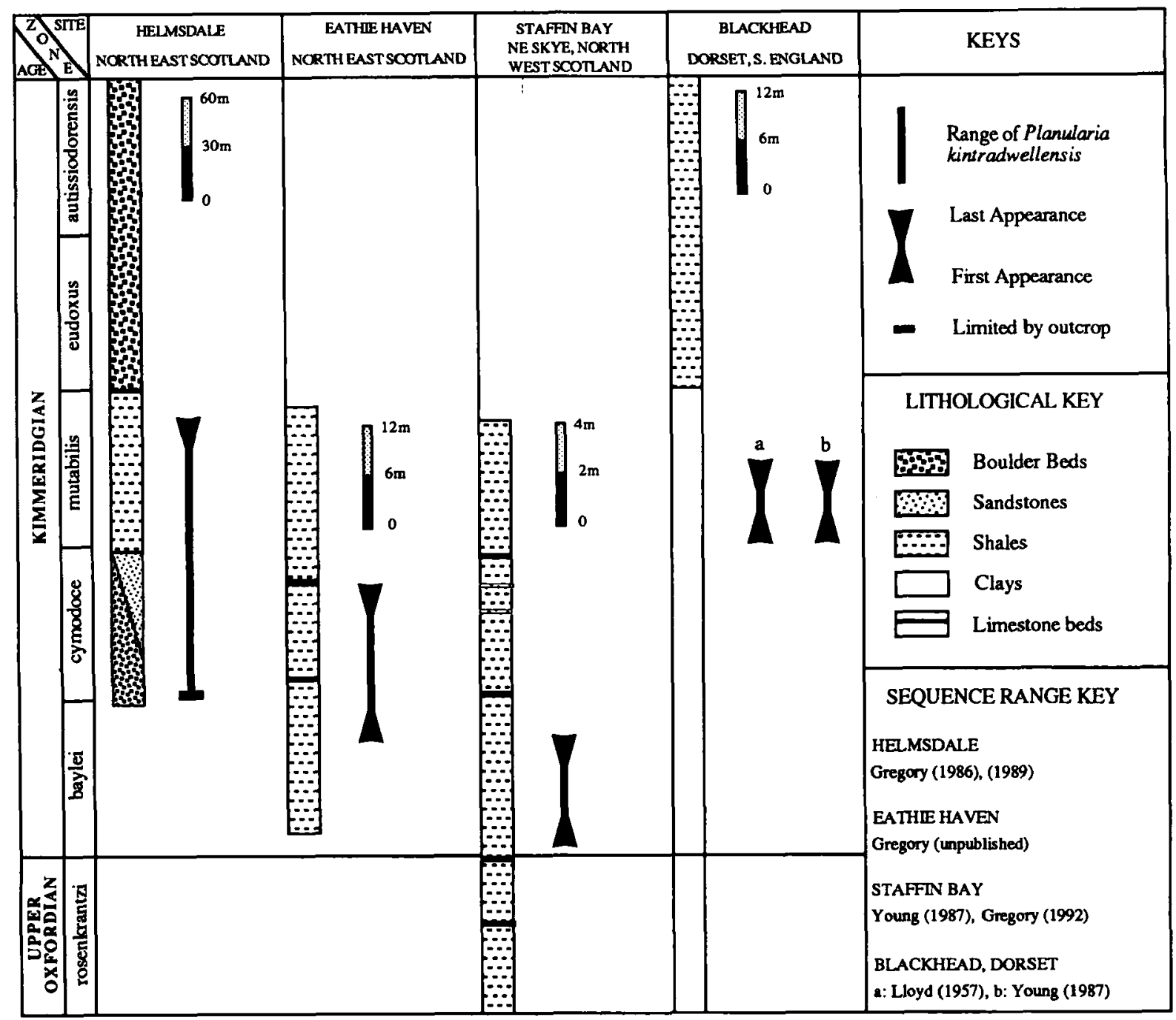

Fig. 3. Distribution of Planularia kintradwellensis from all the sites, also included are lithological logs recording the main facies types present and the exact stratigraphical distribution of $P$. kintradwellensis.

biostratigraphy is well established from the work of Arkell (1933, 1947) and Cox \& Gallois (1981) and the sequence is typified by shales and clays, with siltstone and limestone markerbands. Micropalaeontological research of the CallovianPortlandian of this particular area has been intense from the initial work of Blake (1875) and Neaverson (1921) which merely listed foraminifera through to the more substantial research of Lloyd $(1958,1959,1962)$, Barnard $(1951,1952)$, Gordon (1965,1966), Shipp (1989) and Young (1987). Planularia kintradwellensis was recovered by both Lloyd (1958) and Young (1987) as Planularia curticostata and Saracenaria sp. 2 respectively. The specimens were collected from the lower parts of the mutabilis Zone.

Interestingly, there are also other sources covering Lower Kimmeridgian sections in the region of the United Kingdom where Planularia kintradwellensis has not been recorded, and these are;

i). South Ferriby, North Humberside, Fig. 1 Point 5. (Young, 1987, Gregory unpublished)
ii).Worlaby Boreholes, South Humberside, Fig. 1 Point 6. (Medd in Richardson 1979).

iii). Lower Kimmeridgian of the Boulonnais, North France (Barnard \& Shipp, 1981).

iv). Offshore Northern North Sea Upper Jurassic (Nagy et al. 1990).

\section{CONCLUSIONS}

Planularia kintradwellensis is a benthonic foraminiferid which appears to be stratigraphically confined to the baylei-mutabilis Zones of the Lower Kimmeridgian of the Boreal and subBoreal deposits in the United Kingdom. Facies dependent distribution, often quoted as a limitation in benthonic foraminiferal biostratigraphy, is not a major limiting factor in the distribution of this taxon. P. kintradwellensis occurs across several facies types, but its colonizing potential is somewhat limited when oxygen depleted conditions prevailed. Migration rate and dispersion lag accounts for the slight discrepancies in the first and last appearances of the foraminiferid in the 
various basins. Until more information from offshore sectors is made available migration routes cannot be predicted with any confidence.

\section{ACKNOWLEDGEMENTS}

I am especially grateful to the following who made this research possible: Britoil plc and Dr. P. Copestake (I.E.D.S. Ltd.) arranged the initial funding and offered comments on the manuscript. The Systematics Association awarded a grant to enable use of Scanning Electron Microscope facilities at Hull University. Shell UK Exploration kindly provided the funding that permitted continuation of the initial research. Dr. H.M. Pedley (Hull University) was my supervisor, offering support during difficult times.

\section{Manuscript received August 1991 \\ Manuscript accepted July 1992}

\section{REFERENCES}

Arkell, W.J. 1933. The Jurassic System in Great Britain. Clarendon, Oxford. $681 \mathrm{pp}$.

Arkell, W.J.1947. The Geology of the country around Weymouth, Sezverage, Corfe and Lulworth. Memoirs of the Geological Survey of Great Britain, $336 \mathrm{pp}$.

Barnard, T. 1952. Foraminifera from the UpperOxford Clay of Warboys, Huntingdonshire. Proceedings of the Geologists Association, 63, 336350.

Barnard, T. 1953. Foraminifera from the Upper Oxford Clay of Redcliff Point, near Weymouth, England. Proceedings of the Geologists Association, 64, 183-197.

Barnard, T. \& Shipp, D.J. 1981. Kimmeridgian Foraminifera from the Boulonnais. Revue de Micropaléontologie, 24, 3-26.

Barron, H.F. 1989. Dinoflagellate cyst biostratigraphy and palaeoenvironments of the Upper Jurassic (Kimmeridgian- basal Portlandian) of the Helmsdale Region, East Sutherland, East Scotland. In Batten, D.J. \& Keen, M.C. (Eds.), North Western European Micropalaeontology and Palynology, 173-192. Ellis Horwood, Chichester.

Blake, J.F. 1875. On the Kimmeridge Clay of England. Quarterly Journal of the Geological Society, 31, 196-237.

Buckman, S.S. 1923. Type Ammonites. Privately Published, 4, 40-44.

Cox, B.M. \& Gallois, R.W. 1981. The stratigraphy of the Kimmeridge Clay of the Dorset type area and its correlation with some other Kimmeridgian sequences. Reports of the Institute of Geological Sciences $U K, 80 / 4,1-44$.

Defrance, J.L.M. 1824. Dictionnaire des Sciences Naturelles. F.G. Levrault, Paris.

Gregory, F.J. 1986. A Study of the Foraminifera and Radiolaria from the Lower Kimmeridgian of the Brora /Helmsdale Outlier, NE Scotland. Unpublished M.Sc. thesis, University of Hull.

Gregory, F.J. 1989. Palaeoenvironmental interpretation and distribution of lower Kimmeridgian foraminifera from the BroraHelmsdale Outlier, northeast Scotland. In Batten, D.J. \& Keen, M.C. (eds.), North western European Micropalaeontology and Palynology, 173-192. Ellis Horwood, Chichester.

Gregory, F.J. (in prep.) Palaeoenvironmental Interpretation of the Middle and Upper Jurassic at Staffin Bay, NE Skye: Evidence from Foraminiferal Palaeoecology.

Gümbel, C.W. 1862. Die Streitberger Schwammlager und ihre Foraminiferen Einschulsse. Jaltreschaft des Vereins für Vaterländische Naturkunde in Württemberg, 18, 192-238.

Hansen, H.J. \& Rögl,F. 1988. Planularia Defrance, 1826(Foraminiferida) proposed conservation. Bulletin of Zoological Nomenclature, 45, 114115.

Haynes, J. R. 1989. The Classification of the Foraminifera- A Review of Historical and Philosophical perspectives. Palaeontology, 33, 508528.

Lee, G.W. 1925. Mesozoic rocks of east Sutherland and Ross. In Read, H.H. \& Phemister, J. (Eds.), The Geology of the country around Golspie, Sutherlandshire, Memoirs of the Geological Survey of Scotland.

Lee, G.W. \& Pringle, J. 1932. A synopsis of mesozoic rocks of Scotland. Transactions of the Geological Society of Glasgow, 19, 158-224.

Levine, N.D., Corliss, J.O. \& Cox, F.E.G. 1980. A newly revised classification of the Protozoa. Journal of Protozoology, 27, 37-59.

Linsley, P.N. 1972.The stratigraphy and sedimentology of the Kimmeridgian deposits of Sutherland, Scotland. Unpublished Ph.D. thesis, University of London.

Lloyd, A.J. 1958.The foraminiferal faunas of the type Kimmeridgian. Unpublished Ph.D. thesis, University College, London.

Lloyd, A.J. 1959. Arenaceous Foraminifera faunas from the type Kimmeridgian. Palaeontology, 1, 298-320.

Lloyd, A.J. 1962. Polymorphinid, Miliolid and rotaliform Foraminifera from the type Kimmeridgian. Micropaleontology, 8, 369-383.

Loeblich, A.R. \& Tappan, H.J. 1964.Sarcodina. Treatise on Invertebrate Paleontology. Part C. Protista. Geological Society of America, University of Kansas Press.

Loeblich, A.R. \& Tappan,H.J. 1974. Recent advances in the classification of Foraminifera. In Hedley, R. H. \& Adams, C.G. (Eds.). Foraminifera, Academic Press, New York, 1-53.

Loeblich, A.R. \& Tappan, H.J. 1984. Suprageneric Classification of the Foraminiferida (Protista). Micropalaeontology, 30, 1-70.

Loeblich, A.R. \& Tappan, H.J. 1988. Foraminiferal Genera and their Classification. 907p., 212p. \& 847 plates. Van Nostrand Reinhold Company, New York.

Løfaldi, M. \& Nagy, J. 1983. Agglutinating Foraminifera in Jurassic and Cretaceous dark shales in Southern Spitsbergen. In Verdenius, J.A., Van Hinte, J.E. \& Fortuin, A.R. (Eds.), Proceedings of the First Workshop on Arenaceous Foraminifera, 91-107. University of Amsterdam/IKU publication.

Margulis, E. 1974. Five kingdom classification and the origin and evolution of cells. In Dobzhansky, T., Hicht, M.K. \& Steer, W.C. Evolutionary Biology. New York, Plenum Press, 745-78.

Morris, P.H. \& Coleman, B.E. 1989. The Aalenian to Callovian. In Jenkins, D.G. \& Murray, J.W. (Eds.), Stratigraphical Atlas of Fossil Foraminifera, 189-236. Ellis Horwood, Chichester.

Morris, P.H. \& Dyer, R. 1990. The Application of Middle Jurassic to Early Cretaceous agglutinated foraminifera to the offshore correlation of the Humber Group sediments in the North Viking Graben. In Hemleben, C., Kaminiski, M.A., Kuhnt, W. \& Scott, D.B. (Eds.), Paleoecology, Biostratigraphy, Paleoceanography and Taxonomy of Agglutinated Foraminifera. 3rd. International Workshop on Agglutinated Foraminifera, 961-967. NATO ASI Series C. Kluwer Academie Publishers, Amsterdam.

Nagy, J. 1985a. Jurassic foraminiferal facies in the Statfjord area, Northern North Sea. Part 1. Journal of Petroleum Geology, 8, 254-273.

Nagy, J. 1985b. Jurassic foraminiferal facies in the Statfjord area, Northern North Sea. Part 2. Journal of Petroleum Geology, 8, 273-295.

Nagy, J., Løfaldi, M., Backstrom, S.K. \& Johansen, H. 1990. Agglutinated foraminiferal stratigraphy of Middle Jurassic to Basal Cretaceous Shales, Central Spitsbergen. In Hemleben, C., Kaminiski, M.A., Kuhnt, W. \& Scott, D.B. (Eds.), Paleoecology, Biostratigraphy, Paleoceanography and Taxonomy of Agglutinated Foraminifera. 3rd. International Workshopon Agglutinated Foraminifera, 969-1015. Kluwer Academie Publishers, Amsterdam. 
Neaverson, E. 1921. The foraminifera of the HartwellClay and subjacent beds. Geological Magazine, 58, 454-473.

Opinion 1571. 1990. Planularia DeFrance, 1826 (Foraminiferida): conserved. Bulletin of Zoological Nomenclature, 47, 60-61.

Richardson, G. 1979. The Mesozoic stratigraphy of two boreholes near Worlaby, Humberside. Bulletin of the Geological Survey of Great Britain, 58, 1-24.

Ride, W.D.L. 1975. International Code of Zoological Nomenclature., 3rd. Edition, 338pp.

Riley, L.A. 1980. Palynological evidence of an early Portlandian age for the uppermost Helmsdale Boulder Beds, Sutherland. Scottish Journal of Geology, 16, 29-31.

Shipp, D.J. 1989. The Callovian to Portlandian. In Jenkins, D.G. \& Murray, J.W. (Eds.), Stratigraphical Atlas of Fossil Foraminifera, 125144. Ellis Horwood, Chichester.

Sykes, R.M. 1975. The Stratigraphy of the Callovian and Oxfordian stages in North Scotland. Scottish Journal of Geology, 11, $51-78$.

Sykes, R.M. \& Callomon, J.H. 1979. The Amoeboceras Zonation of the Boreal Upper Oxfordian. Palaeontology, 22, 839-903.

Turner, J. 1966. The Oxford Clay of Skye, Scalpay and Eigg. Scottish Journal of Geology, 2, 243-252.
Turner, J. 1970. The ammonites of the Bukowskii Subzone of the Oxfordian of Skye. Scottish Journal of Geology, 6, 371-378.

Waterston, C.D. 1950. Notes on the Sandstone Injections of Eathie Haven, Cromarty. Geological Magazine, 87, 133.

Waterston, C.D. 1951. The Stratigraphy and Palaeontology of the Jurassic rocks of Eathie (Cromarty). Transactions of the Royal Society of Edinburgh, 62, 35-52.

Wright, J.K. 1973. The Middle and Upper Oxfordian and Kimmeridgian Staffin Shales at Staffin. Proceedings of the Geological Association, 84, 447-457.

Wright, J.K. 1989. The early Kimmeridgian ammonite succession at Staffin, Isle of Skye. Scottish Journal of Geology, 25, 263-272.

Young, R.L.A. 1987.The Palaeoecology of Jurassic Foraminifera from selected sequences in Great Britain with particular emphasis on the Suborder Robertinina. Unpublished Ph.D. thesis, University of Hull.

Zeigler, B. 1962a. Die Ammoniten-Gattung Aulacostephanus im Oberjura (Taxonomie, Stratigraphie, Biologie). Paläontologie Abhandlungen $A, 119,1-172$.

Zeigler, B. 1962b. Some Upper Jurassic ammonites of the genus Rasenia from Scotland. Palaeontology, 5, 765-769. 